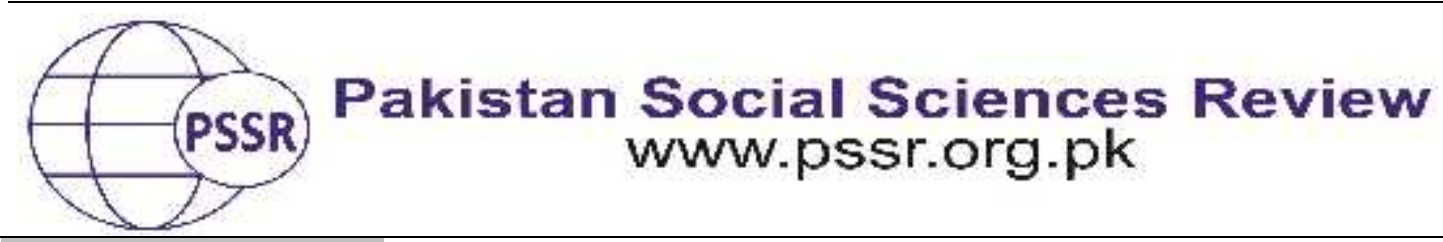

RESEARCH PAPER

\title{
Cultural Heritage and Extremism in Pakistan: Re-focusing on the Kalasha of (Chitral) Pakistan
}

\author{
Muhammad Kashif Ali ${ }^{1}$ Muhammad Iqbal Chawla ${ }^{2}$ Ghulam Shabbir ${ }^{3}$
}

1. Lecturer, Department of History \& Pakistan Studies, University of Gujrat, Punjab, Pakistan

2. Former Dean Faculty of Arts and Humanities, University of the Punjab, Lahore, Punjab, Pakistan

3. Lecturer, Department of History \& Pakistan Studies, University of Gujrat, Punjab, Pakistan

\begin{tabular}{|c|c|}
\hline NFO & $\mathrm{CT}$ \\
\hline $\begin{array}{l}\text { ed: } \\
\text { ry } 27,2020 \\
\text { ed: } \\
15,2020 \\
30,2020\end{array}$ & $\begin{array}{l}\text { This study attempts to explore, investigate and analyse causes } \\
\text { and consequences of the pliability of the cultural heritage of } \\
\text { Pakistan which is showing the signs of disappearing on the eve } \\
\text { of extremism in Pakistan particularly of the Kalasha by focusing } \\
\text { on the Kalasha people. The Kalasha were raided by the Muslims }\end{array}$ \\
\hline $\begin{array}{l}\text { Keywords: } \\
\text { Cultural, } \\
\text { Tourism, } \\
\text { Extremism, } \\
\text { Governance } \\
\text { Issues } \\
\text { Kalasha Tribe, } \\
\text { Minorities, } \\
\text { Pagan Tribe, } \\
\text { Talibanization }\end{array}$ & $\begin{array}{l}\text { inthe } 14^{\text {th }} \text { century. The demarcation of Durand Line (Pak-Afghan } \\
\text { border) in } 1893 \text { became their lifeline when they fell to the British } \\
\text { Indian government while their tribe fellows at the other side of } \\
\text { the Pak-Afghan border in Afghanistan were forcefully converted } \\
\text { as a whole in } 1896 \text {. Somehow, the Kalasha of Pakistan were } \\
\text { leading their life according to their dastoor (culture \& religion) } \\
\text { and then military coup of } 1977 \text { brought ill-fate for them under } \\
\text { pseudo Islamization of military ruler Gen. Zia-ul-Haq. The } \\
\text { Talibanization/extremism suppressed the Kalasha indigenous } \\
\text { tribe. The event of } 9 / 11 \text { devastatingly hit the tribe for their faith }\end{array}$ \\
\hline $\begin{array}{l}\text { Correspondin } \\
\text { Author }\end{array}$ & $\begin{array}{l}\text { War on Terror many extremists and terrorist groups } \\
\text { mushroomed, especially in tribal agencies and in Khyber } \\
\text { Pakhtunkhwa. Tehrik-i-Taliban Pakistan recently threatened the } \\
\text { Kalasha to convert their faith or to be ready for genocide. The } \\
\text { Kalasha people are seeking their survival through their unique } \\
\text { identity. They could earn soft image trait for Pakistan, but } \\
\text { unfortunately, extremism, terrorism and ill-governance of the } \\
\text { state losing it for decades. If the government failed to protect } \\
\text { them, we will lose a unique tribe and culture. }\end{array}$ \\
\hline
\end{tabular}

\section{Introduction}

The Kalasha is an indigenous tribe of Chitral, three mountainous valleys of Biriu, Rukmu and Mumuret (however these valleys are known to non-Kalasha as 
Birir, Rumbur and Bumburet) of the Hindu Kush are their abode, in the foremost north-western district Chitral, KPK. The Kalasha community was living in isolation for centuries until the first jeep-able road was built in the region in the 1970s (Ahmed, 1986). The said road opened the door of the outer World to Kalasha and vice versa (Ali, 2010).The Kalasha are the Dardic people and speak the Indo-Dardic language; the Kalashamun (Ali, 2019). Different theories prevail regarding the origin of the Kalasha. These theories are based on myths, folklores, historical analysis, archaeological studies, linguistics and genetic studies. As the historical discussion is not my course to the current paper, so in short, the local claim that they are from an unknown land Tsyam (Saifullah Jan, 1996), some classical writers suggested them as Greek and genetic studies dispelled Greek ancestry hypothesis that the Kalasha people are from Aryan stock (Ayub, 2004). The Kalasha of Pakistan are practicing their unique culture and religion for centuries. Collectively, they call their religion and culture as dastoor. Their dastoor is distinctive to the rest of Pakistan.

\section{Research Methodology}

For the study, the historical descriptive method coupled with an analytical approach was adopted. This is a qualitative study, primary and secondary both type of source were consulted. For better understating the community, their culture and vulnerability it was required to stay with the community understudied. Therefore, ample time was spent in the Kalashdesh in different seasons and during festivals for observations and interviews, from 2007 to 2017.

\section{Literature Review}

Anthropological the Kalasha community is well studied however their history was neglected in-depth, the first doctoral dissertation (Parkes, 1983) on the community was produced in 1983 and its focus was anthropological study specifically the social order and marriages of elopement. Wynne Maggi, an American anthropologist, submitted her doctoral dissertation (Maggi, 1998) to Emory University and her dissertation purely deals with the status of the Kalasha women. Zaheer-ul-Din, a local Chitrali scholar, also has conducted his doctoral dissertation (Zaheer, 2011) on the community and he has studied their religion indepth with the comparative approach and the dissertation was submitted to International Islamic University through the Department of Comparative Religions. Though his works discuss the Kalasha religion and impact of other religions and event of 1896 but the dissertation was submitted in 2011 so it was need of time to update the subject of extinction of the tribe. Irum Sheikh earned her PhD (Sheikh, 2013 ) in 2013 in anthropology but her area of study was only one valley; Bumburet. She discusses the culture and society of the community but the historical portion is weaker even there are some misunderstanding as well. Muhammad Kashif Ali has conducted his MPhil research in summers of 2007 and 2008 to study the cultural change of the community, though in the study (Ali, 2010) history of the tribe was discussed but very precisely and the major focus of the dissertation was the cultural change rather than in-depth historical studies of all practicing and converted 
Kalasha valleys. There are handsome sources to study the culture and society of the community with least focus on their history from ancient to modern times, this study specifically is an attempt to explore the one aspect of the Kalasha history; extremism and conversion.

The Terrorism and Extremism is a universal phenomenon and no society is free from it. However, the nature of extremism and terrorism of each society or country may vary depending upon the local and international factors (Ahmar, 2011). Pakistan has also been affected by extremism in different eras for different factors. Umbreen Javaid narrates, "The mixture of extremism with militancy has brought about an explosive situation to Pakistan's internal as well as external security." (Javaid, 2011) She further adds that at the early phase of Pakistan the religion had the least impact on politics but later the religion was exploited widely by the political leadership of Pakistan and "Religion started playing a crucial role in Pakistan during the Zia regime and the Afghan war left grave social, economic, political and religious impact on Pakistan" (Javaid, 2011). The same can be applied to the micro ethno religious minority of Pakistan, the Kalasha were also hit by the religious extremism especially during the Zia regime and on the other hand, the Islamic Revolution of Iran boosted up the religious fanaticism in the region, later War on Terror badly hit the region and the Kalasha community.

The current study is divided into three major portions or phases of extremism in the history of the Kalasha from the late 19th century to the modern era:

\section{Religious Conversion by Amir Abdur Rahman Khan}

Until the 19th century the Red Kafirs or Kafirs (Lit. non-believers) were living in Kafiristan (Lit. the land of the non-believers); a north-eastern semi-autonomous region of Afghanistan. The Kafiristan was abode of animist tribe. The Red Kafirs (of Kafiristan) and Black Kafirs (of Chitral) had some ethnic and lingual similarities. Historian suggested that, once, all Kafirs (of the Hindu Kush) were one group, which later subdivided into two major groups; Kalasha Kafirs or Black Kafir and Kati or Red Kafirs. The Kafirs had continued to follow their unique faith and strongly resisted attempts by Afghan to conquer the Kafiristan. It was a crucial period of the Great Game when the British and the Russian imperial powers were competing with each other to engulf the Central Asia and Afghanistan. The region experienced three Anglo-Afghan Wars (1839-1842, 1878-1880 and 1919). In 1880, Abdur Rahman Khan (also known as the Iron Amir) became the Amir of Afghanistan in 1880 and he tried to settle the issues bilaterally with British. Amir Abdur Rahman signed the Durand Line Agreement with British in Kabul in 1893 which changed the destiny of Red Kafirs and Kalasha Kafirs as Kalasha Kafirs were in a better position in British India (Maggi, 2001). Now, the Afghan Amir was relaxed from the British side and it created an opportunity for Amir Abdur Rahman to declare a war against the preIslamic ethno religious group; the Red Kafirs of Kafiristan (Khan, 2009). The Kafiristan was invaded in 1896 and fell to Afghan kingdom. The Red Kafirs had limited choices; conversion, forced migration or genocide. Majority of them were converted and some fled across the Durand Line and settled in the British India, in 
border villages of Kalasha Kafirs in Chitral (then Chitral state) (Ali, 2010). It was a forced conversion led by the state; however, Amir Abdur Rahman denied it in his autobiography (Khan, 1900).

So, this was the first major setback and threat to the indigenous people, to their unique cultural heritage and primitive traditions. As for the animist and pagan tribe, it was closing a chapter of history. Majority of the Kafirs converted to Islam and some took refuge in Kalasha valleys of Chitral. The Kalasha valleys were Jinjeret Kuh, Birir, Rumbur and Bumburet. The Kafiristan was given the new name Nuristan (Lit. the land of light) (Ahmed, 1986). The Durand Line became the blessing and fatal at the same time; fatal for the Red Kafirs and blessings for the KalashaKafirs (Loude\& Lievre, 1988).

\section{Islamization of Kalasha People during Muhammad Zia-ul-Haq's Regime}

In mid of the $20^{\text {th }}$ century, two sovereign states emerged; Baharat (India) and Pakistan from British India. Before the partition in British India, internal independent principalities were more than five hundred. Those princely states were ruled by local princes called Khan, Nawab, Mir etc. The states, internally, were independent with the acceptance of the superiority of the English Empire. Ch. Muhammad Ali writes that the states, at the time of partition, were made sure to annex Pakistan or India as it was decided in the famous $3^{\text {rd }}$ June Plan. (Ali, 1988). Mehtar Muzaffar-ul-Mulk: ruler of Chitral, declared accession to Pakistan in August 1947, whereas the agreement of accession between the Chitral state and government of Pakistan was signed later in November 1947 (Baig, 1997 \&Bangash, 2015). Chitral was the first state, according to historical records, to accede to Pakistan (Zaidi, 2003).

Once Mehtars: rulers of Chitral, were under direct influence of the British government through British Political Agent. Now, the Chitral State was administrated by Pakistan Government through a Political Agent since 1950. However, there was a shift in the status for Chitral state as an agency in 1966 and the political agent was entitled as Wazir-i-Azam (premier) by the Government of Pakistan (Khan, 2013). The early decades of Pakistan were a happy time for the Kalasha community. Although the said period was not good enough as socially and economically for the Kalasha community, however, their ethnic and religious identity was never threatened by the state or individual. Siafullah Jan Kalash credited Ayub Khan's government for providing some relief and the identity of the Kalasha community (Saifullah Jan, 1996). However, it was Zulfiqar Ali Bhutto who realized the importance of indigenous tribe. He was the first Pakistani ruler who visited Bumburet Kalash valley and addressed to a pre-Islamic tribe, the tribe was encouraged to follow their ancient religion and traditions (Ibid).

During the despotic rule of Muhammad Zia the Kalasha tribe experienced the unfriendliness, vulnerability and drastic change in their society and dastoor, their dastoor went under pressure. During the said period the conversion cases of the tribefellows were speeded up. Kanwal believes that the Islamic Revolution of the Islamic 
Republic of Iran and the US-Russian war in Afghanistan, during the 1980s, helped enormously Muhammad Zia-ul-Haq for Islamization in Pakistan (Kanwal, 2015). Zaidi claims that around 1981 a mosque was built forcefully on cultivable land of primitive tribe-fellow in Bumburet valley and it triggered conflict and Islamization in the Kalashdesh. He further claims that the Kalasha were badly affected by USfinanced jihad in Afghanistan, as a great number of Afghans took refuge in Pakistan and Chitral, and some of the refugees seized the forests or pastures of the Kalasha people (Zaidi, 2001). The economy and society of the Kalasha is agro-pastoral which primarily rely upon their cattle and flocks for a larger portion of their income.Their herds, pastures and forests are lifeline not only for their economy but for their dastoor at the same. The Kalasha religious rituals revolve around their sheep and goats as they offer sacrifices of their animals in great numbers throughout the year. Therefore, if there is any loss of pastures or forests, it leads directly towards the decay of their dastoor. Zaidiclaims, that 70 percent of Kafir (Kalasha) land was seized by the Afghan refugees in 1980s and 1990s, he also blamed Patahntablighi parties later known as Taliban (Zaidi, 2001).

One of the key informants: Din Muhammad Kalash verified that during the despotic rule of General (R) Muhammad Zia-ul-Haq some Kalasha tribe-fellows were provided the loans by tablighis, and later when they were unable to payback, they converted to seek the religious empathy. (Din Muhammad Kalash, personal communication August 23, 2007).Zaidi assumed it as forced conversion while Ahmed disagreed with Zaidi's claim of forced conversion, Ahmed (1986) writes, "Why does a Kalash become a Muslim? Sometimes to escape a ruinous debt, sometimes to gain employment, sometimes, as in the cases of many women, to find spouses and through them a higher standard of living. But rarely does he become a Muslim by physical force." The present author during various field visits to all three Kalasha valleys in the last decade never heard forced conversion cases. Local historian Prof. MumtazHussian also verifies it that he never happened to hear forcefully conversion cases in the valleys, however, he claims that there had been small scale tabligh in the valleys (Mumtaz Hussain, personal communication March 16, 2018). Ishtiaq Ahmed, a contemporary political historian, writes that under the Zia regime there was a demand to declare the all non-Muslims as zimmis by some ulema and it was also added to collect the religious tax jizyafrom them; and it was a great shift towards policy (Ahmed, 2008).

There was instability on political grounds in Pakistan from 1988 to 1999, after Muhammad Zia-ul-Haq. In the said period four civil governments were dissolved. Therefore, none of the governments of the four could focus the minorities' rights, including the Kalasha of Chitral. During the first termof Mian Muhammad Nawaz Sharif, one school for the Kalasha children was established by a minority representative of National Assembly, in 1991. The first time it happened that in the said school the teachers were hired from the Kalasha community (Ali \&Rehman, 2001). 


\section{Threats to Kalasha Dastoor after 9/11 Era}

The $21^{\text {st }}$ century brought a real threat to the survival of the marginalized indigenous Kalasha tribe. In 1999, another military ruler, Pervez Musharraf, dissolved the democratic government. The Musharraf's regime is considered liberal, while another major characteristic of the said regime was extremism. By nature, Pervez Musharraf was a liberal, while extremism in the state has mushroomed as a by-product of War on Terror. After Zia, it was the second time that extremism was experienced in Pakistan. The general opinion of Chitral people was positive towards Musharraf for his relaunching the Lowari Tunnel project after suspension of a long time, on the other hand,it is fact Pakistani society had to experience extremism as the result of Musharraf's policies towards War on Terror.

Lakshan Bibi Kalash, a resident of Rukmu valley, was interviewed in 2007 by The Washington Times, she told during the interview that some of the Kalasha young men were brainwashed by their Muslims teachers and later they participated in the war in Afghanistan (Smucker, 2007b). She did not feel comfortable with government schools in the Kalashdesh. She spoke to The New York Times thather tribe fellowswere surrounded by the Muslims and were being crushed by the Talibanin response to War on Terror motivated by the US President George Bush (Smucker, 2007a).

Before the event of 9/11, the whole region beyond the Lowari Pass was remarkably peaceful territory. However, in later years due to its geography and due to sharing boundaries with Afghanistan the district Chitral had suffered a lot. Afghan President Hamid Karzai, a strong ally of US, alleged in December 2006 that Osama bin Ladden: Al-Qaeda leader, had hidden himself among the Kalasha of Chitral (Zahiruddin, 2006). The Hindu, the Indian paper, also reported a story that Bin Ladden was hidden in Chitral and was being searched by US drones on regular bases (Osama in Chitral, 2009). Even though the episode of Bin Ladden's refuge in Kalashdesh or Chitral was not verified by any official source from the US or Pakistan, but it triggered the fear among the microscopic minority of Chitral. While comparing the peaceful situation in ChitralFarzana Shah (2009) reported that in the whole district of Chitral there were only 9 police stations while police posts were 20 till 2009 for the population of about three and a half lacs. In the latest visit to Kalashdesh, the current researcher counted six check posts in the small valley of Rumbur (of three thousand population) in summer of 2017. Once Urtsun and JinjiretKuh valleys were inhabited by the Kalasha people, now both valleys have been convertedand not opened to the non-residents due to security sensitivity as both valleys are very close to Durand Line. Today, the Kalasha are living in onlythree valleys; Biriu, Rukmu and Mumuret. However, non-residents are not allowed to visit whole valleys, upper valleys are banned for non-residents. The primary author planned, in the summer of 2015, to spend ample time with Kalasha herdsmen at Bahuk pasture, (of Rukmu, nearby the Pak-Afghan border) but the permission was not granted to hike towards Bahuk by army personnel stationed at 
the western neck of the valley until the permission from higher authorities at Chitral town was granted, after a labour of a couple of days.

The Durand Line, once served as a lifeline for the Kalasha people in 1896 when Kafiristan (Afghanistan) was raided by Amir Abdur Rahman, many were killed (Azar, 2006) as Azar recordsand many of them were made slaves(Maraini, 1964). Almost all Red Kafirs of Kafiristan had to convert to Islam and the name of Kafiristan was changed to Nuristan by Amir (Khan, 1900). Only a little number of them could take refuge in Kalashdesh (in British India). The Kalasha of Chitral could survive from the raid of Afghan ruler because the Kalasha were subject of British India. Historically, 1896's event was the sole event when Durand Line became the lifeline for the Kalasha tribe, otherwise, the Durand Line had been an element of fear for this community. They had fear of raids of Red Kafirs (after conversion Nuristani) who were used to attack the Kalasha high pastures for their herds. The Post 9/11 era brought intense tension for the community. Now, across the border in Afghanistan Talibanization was intensity and it was relentless element of terror for the Kalasha and the Muslims of Kalashdesh. In every summer the local shepherds migrate from valleys to pastures nearby the Durand Line where their herds keep grazing for whole summer. In the summer season when the snow melts it adds the fear of raids from Taliban or Nuristanis across the border. For instance, according to Luke Rehmat key informant of the author, in September, ten workers were kidnapped from the forests of Bumburet valley and four of them were killed brutally with a message of not fight with Taliban (Ali, 2019).

In summer of 2012, another tragic incident happened during the field visit of the present researcher, in the high pasture of Bumburet valley adjacent to Afghanistan, a young herdsman from the Kalasha community was ruthlessly killed while about 700 goats were kidnapped which were taken to Afghanistan. Reportedly, thirty Afghan Taliban raided from Nuristan side (Mohakm-ud-Din, 2012). Then, in Kalashdesh, it was time to celebrate the great festival Uchaw. That young slain shepherd was from Bumburet valley, therefore, elders of the valley, the first time in recent history, cancelled the festival for the said year in Bumburet, however in other two valleys of Rumbur and Birir it was celebrated half-heartedly. The faces, expressions and feelings of the Kalasha participants during a celebration in Rumbur were gloomy, the present author personally observed it during Uchaw. Again in September 2016, two herdsmen were ruthlessly killed by the Taliban from Afghanistan and about 300 goats were abducted to Afghanistan (The News, July 30, 2016).

This kind of incidents is alarming for the Kalasha community as goat and sheep are the backbone of their economy as well as very important for their dastoor. Due to frequent attacks from Nuristan the locals are losing their herds greatly. Muhammad Khan, my informant, told that before the event of 9/11 the local shepherds had weapons with them for their survival in high pastures, but now the security agencies of Pakistan do not allow them to take any kind of weapon with them. Therefore, at the time of attack from Nuristan the local shepherds feel helpless (Muhammad Khan, personal communication, July 28, 2015). Almost all major 
pastures like Ostui, Gangalwat. Bahuk, Chimiksun etc. take one day hike from main valleys. If the local shepherds are raided across the border, it is not possible for security personnel to rescue them from valleys until the permanent security posts are established alongside the Durand Line or the local shepherds are permitted to take their weapon with them to the high pastures.

The locals are not the sole victims of the Afghan Taliban, they did not spare, in recent past, well-wisher of the community. A Greek volunteer and teacher by profession: Athanasious Lerounis, was greatly well-wisher of the Kalasha people and the community itself had great respect for him. In the early 1990s, he visited the valleys and decided to uplift the marginalized community by his welfare activities in the valleys. During a field visit, he was interviewed, in summer 2008, by the present author and told that he was used to spend his summer vacations in Kalash-Chitral. Till 2008 Lerounis had established five Kalasha schools and one ethnological museum: called Kalashadur in Brun village of Bumburet valley (Athanasious Lerounis, personal communication, May 15, 2008). One year after the interview with the present author, in September 2009 Afghan Taliban attacked the Kalashadur in the dark of night, the guard at the museum was killed, while Lerounis was kidnapped and shifted to Nuristan. The news was spread globally besides the national media. According to a story of The Telegraph the Afghan Taliban demanded from Pakistan Government $£ 1.25$ million along with the release of some Taliban commander (Nelson \& Khan, 2009) The community was very touchy regarding Lerounis, therefore a Kalasha delegation led by Mr. WazirZadaKalasha, now MPAKP assembly, went Afghanistan to meet the Taliban commander for negotiation (Ali, 2019). After the efforts of many months, though, Mr. Lerounis was released and he brought to Pakistan before leaving for Greece, but, this type of incident increased the sense of insecurity for the community and their well-wishers as well.

The recent major cultural and survival collision was faced by the community in February 2014, when they received a terrifying threat from Tehrik-i-Taliban Pakistan (TTP). According to a national daily, the TTP released a videotape in the said month and threatened the Kalasha community to embrace Islam, by force. In the video, the international NGOs were alleged to preserve the polytheistic belief of the community. Further, in the video, the Ismaili community was also warned to change their beliefs, if failed the community was threatened for killing. (Pakistani Taliban threaten Kalash tribe, Ismailis in Chitral, February 12, 2014). Such kind of threat was a great source of fear for the marginalized minority of Chitral. However, it was a good gesture that such kind of threat was condemned by the different pillars of the state. First of all current Prime Minister Imran Khan, then as Chairman Pakistan Tehrik-i-Insaf condemned the message from TTP. (Imran flays TTP threat to Kalash tribe, Ismailis, February 15, 2014). The judiciary was second to condemn it after three weeks of the video was appeared. Tassaduq Hussain Jillani, the Chief Justice Supreme Court of Pakistan, reacted and timely soumotu notice was taken against the threat and he inquired from the Attorney General that what measures were being taken for the protection of both communities (The Dawn, February 20, 2014). He 
further added that the threats were contrary to the Constitution of Islamic Republic of Pakistan, under the clauses 9, 20 and 36. He called it against Islam and tolerance (Nizamani, February 20, 2014).

\section{Conclusion}

It was a concise study and of extremism faced by the pre-Islamic and marginalized tribe of the Hindu Kush, as the by-product of 9/11 and War on Terror. From the inception of Pakistan till Zia's regime the whole region (alongside the Durand Line) was very tranquil and peaceful. However, the situation started to get worst after USSR invasion in Afghanistan and got worsen after US military intervention in the region. The tourism industry has been badly affected; the Kalasha valleys receive very least international tourists as compared to the past.

The Kalasha is the sole pagan tribe of Pakistan practicing its unique religion and culture in the mighty Hindukush for centuries. They are peaceful and content people through history. Before the arrival of Muslim rulers, they were ruler of the whole Chitral valley, from north to south. There was no major threat to their identity until the incident of Amir Abdur Rahman Khan in late 19th century, after that they lived in peace for a long time until US-Soviet war in Afghanistan, which promoted extremism in Pakistan as well. The War on Terror brought another wave of extremism and this time this wave badly hit the pagan tribe as well.

We should keep in mind that the Kalasha society revolves around their festivals. They celebrate many festivals (Zoshi, Uchaw, Pul, Chowmos etc.) round the year, their festivals are socio-religious in nature and survival of the festivals is on their herds. The goats and sheep in great number are sacrificed during festivals and for rituals of death, marriage and (Ali \& Chawla, 2019). If we exclude the animals it means we are fading the festivals, we are putting their religion at risk. If the pastures, shepherds and herds are not protected, it means their culture is at stake, it is not protected. As it has been discussed that the community is anagro-pastoral society which chiefly reliesupon their herds for their economy. Their second major source of income is tourism industry. Both sources are under threat for the same reason; extremism. I can recall the Uchaw festival of 2012 when I saw very least Kalasha tribe fellows at charsu (dancing floor) for ritual dance and asked the reason from Muhammad Khan: the key informant. He replied that the people were frightened and they preferred to stay at home. In fact, in August 2011 some Afghan militants attacked check posts of Pakistan in Chitral area, near Kalash valleys and 26 paramilitary soldiers and policemen lost their lives (The Dawn, August 27, 2011)which was alarming for the pagan tribe. After the incident, the security was increased in Chitral and on Pak-Afghan border the Durand Line. Urtsun and JinjiretKuh could be potential destinations for tourists, as about a century ago both valleys were the Kalasha and later converted, but both valleys are closed for visitors for security reasons. Although Bumburet, Rumbur and Birir are opened valleys for tourists, but only lower parts of the valleys, while upper portions and pastures are "closed" for tourists. 


\section{References}

Ahmar, M. (2011). The challenge of extremism in Pakistan: Are there Lessons to be Learnt from the Experience of Singapore. IPRI Journal, 11 (2), 44-63.

Ahmed, A.S. (1986). Pakistan Society: Islam, Ethnicity and Leadership in South Asia. Karachi: Oxford University Press.

Ahmed, I. (2008) Religious Minorities in the European Union and Pakistan: Historical Comparisons. In P.I. Cheema (Ed.), Political Role of Religious Communities in Pakistan. Islamabad: Institute for Security and Development Policy \& Islamabad Policy Research Institute, 2008).

Ali, C.M. (1988). The Emergence of Pakistan. Lahore: Services Book Club.

Ali, M. K. \& Chawla, M. I. (2019). Socio-Cultural Life of the Kalasha People of Chitral: A Study of their Festivals. Pakistan Vision, 20 (2), 42-57.

Ali, M.K. (2010). Transitions in Kalash Valley (1947-2006). M.Phil dissertation, University of the Punjab, Lahore.

Ali, S.S. \&Rehman, J. (2001).Indigenous People and Ethnic Monitories of Pakistan: Constitutional and Legal Perspective. Richmond: Curzon Press.

Ali. M.K. (2019). A History of the Kalasha in Pakistan: Its Origin, Change and Continuity. Doctoral dissertation, University of the Punjab, Lahore.

Azar, S.M.A.K. (2006). My Heartrendingly Tragic Story, (A.M. Cacopardo\& R.L. Schmidt, Ed.). Oslo: Novus, 2006.

Baig, R.K. (1997). Hindu Kush Study Series, Vol. II. Peshawar: Rehmat Printing Press.

Bangash, Y. K. (2015). A Princely Affair: The Accession and Integration of the Princely States of Pakistan, 1947-55. Karachi: Oxford University Press.

Cacopardo, A. \& Cacopardo, A (1996). The Kalasha in Southern Chitral, Part III: JinjiretKuh and the Problem of Kalasha Origin. In E. Bashir \&Israr-ud-Din (Ed.), Proceeding of the Second International Hindu Kush Cultural Conference. Karachi: Oxford University Press.

Imran flays TTP threat to Kalash tribe, Ismailis. (2014, February 15). The Nation.

Jan, S. (1996). History and the Development of the Kalasha. In E. Bashir \&Israr-udDin (Ed.), Proceeding of the Second International Hindu Kush Cultural Conference. Karachi: Oxford University Press.

Javaid, U. (2011). Partnership in War on Terror and Mounting Militant Extremism in Pakistan. South Asian Studies, 26 (2), 227-239. 
Kalash, D. M. (2007, August 23). Islamization of the Kalasha. (M. K. Ali, Interviewer).

Kanwal, L. (2015) Zia, Islam and Politics of Legitimacy.Al-Dawa, Vol. 30, No 43, 3952.

Khan, M. (2015, July 28). Extremism and the Kalasha. (M. K. Ali, Interviewer).

Khan, M.A. (2013).Chitral and Kafiristan: A Personal Study. New York: Ishi International.

Khan, S.M. (Eds.). (1900). The Life of Abdur Rahman: Amir of Afghanistan, Vol. I. London: John Murray.

Khan, T. (2009). Kalasha Valleys: A Call for Indigenous Cultural Survival. Maters thesis, Central European University.

Lerounis, A. (2008, May 15). Kalasha of Chitral. (M. K. Ali, Interviewer).

Loude, J. Y. \& Lievre, V. (1988).Kalash Solstice. Islamabad: LokVirsa.

Maggi, W. (2001). Our Women are Free: Gender and Ethnicity in the Hindukush. Doctoral dissertation, The University of Michigan Press.

Mansoor, A. et al, (2004). Investigation of the Greek Ancestry of Populations from Northern Pakistan.Human Genetics, Vol. 114, No. 5, 484-490.

Maraini, F. (1964).Where Four Worlds Meet: Hindu Kush 1959. London: Haish Hamilton.

Marx, E. (1999). How We Lost Kafiristan. Representations, No 67, 44-66.

Mohakm-ud-Din. (2012, August 17). Afghan militants storm Kalash Valley, steal herd of goats. The Express Tribune.

Nelson, D. \& Khan, E. (2009, September 21). Taliban targets descendants of Alexander the Great. The Telegraph.

Nizamani, S. (2014, February 20). SC takes notice of threat to Kalash, Ismailis. ARY News.Retrieved from https://arynews.tv/en/sc-takes-notice-threat-kalashismailis.

Osama in Chitral (2009, March 16) The Hindus.

Pakistani Taliban threatenKalash tribe, Ismailis in Chitral. (2014, February 12). The Dawn. 
Parkes, P.S.C. (1983) Alliance and Elopement: Economy, Social Order and Sexual Antagonism among the Kalasha (Kalash Kafirs) of Chitral. Doctoral dissertation, University of Oxford.

Shah. F. (2009, March 22). Osama Bin Laden in Chitral, Pakistan: Another US Expert Guess or calculated tactical move?.Asian Tribute.

Sheikh, I. (2013).Traditional Culture as a Space for Identity (A Case Study of Village Bumburet Kalash Valley).Doctoral dissertation, Quaid-i-Azam University.

Smucker, P. (2007a, June 28). A View from the Roof of the World.The New York Times.

Smucker, P. (2007b, July 09). Jihadists Attack Ethnic Group in Pakistan.The Washington Times. The Dawn. (2011, August 27).

The Dawn. (2014, February 20).

The News. (2016, July 30).

Yapp, M. (2008). The legend of the Great Game.In Proceedings-British Academy.vol. 111.Oxford University Press.

Zaheer-ud-Din.(2011). Foreign Impacts on the Religion of the Kalash. Doctoral dissertation, International Islamic University.

Zahiruddin. (2006, December 29). Chitral Meeting Condemns Afghan Claim about Osama The Dawn.

Zaidi, A. (2001). Ethnic Cleansing of the Kafirs in Pakistan. In The Best of Gowanus: New Writing from Africa, Asia and the Caribbean. New York: Gowanus Books.

Zaidi, Z.H. (Eds.) (2003) Jinnah Papers: The States Historical Policy Perspective and Accession to Pakistan Vo. VIII. Islamabad: Quaid-i-Azam Papers Project. 